\author{
McDonald, TJ ${ }^{1,2}$ and Perry MH ${ }^{1}$ \\ 1: Blood Sciences, Royal Devon and Exeter NHS Foundation Trust, Barrack Road, Exeter, EX2 5DW \\ 2: University of Exeter Medical School, RILD Building, Barrack Road, Exeter, EX2 5DW
}

\title{
Detection of C-peptide in urine as a measure of on-going beta cell function
}

Correspondence: Timothy McDonald, RILD building, University of Exeter Medical School, Barrack Road, Exeter, Devon, EX2 5DW, UK

Email: Timothy.mcdonald@nhs.ac.uk

Telephone +44 (0)1392402948

Fax: +44 (0)1392 402904 


\section{SUMMARY}

C-peptide is a protein secreted by the pancreatic beta cells in equimolar quantities with insulin, following the cleavage of proinsulin into insulin. Measurement of C-peptide is used as a surrogate marker of endogenous insulin secretory capacity. Assessing C-peptide levels can be useful in classifying the sub-type of diabetes as well as assessing potential treatment choices in the management of diabetes.

Standard measures of C-peptide involve blood samples collected either fasted or, most often, after a fixed stimulus (such as oral glucose, mixed meal or IV glucagon). Despite the established clinical utility of blood C-peptide measurement, its widespread use is limited. In many instances this is due to perceived practical restrictions associated with sample collection.

Urine C-peptide measurement is an attractive non-invasive alternative to blood measures of beta-cell function. Urine C-peptide creatinine ratio measured in a single post stimulated sample has been shown to be a robust, reproducible measure of endogenous C-peptide which is stable for three days at room temperature when collected in boric acid. Modern high sensitivity immunoassay technologies have facilitated measurement of C-peptide down to single picomolar concentrations.

\section{KEY WORDS}

C-peptide, Urine, UCPCR, Endogenous, Insulin 


\section{INTRODUCTION}

Insulin secretory capacity can be assessed by measuring C-peptide, a protein secreted by the pancreas in equimolar quantities with insulin, following the enzymatic cleavage of proinsulin into insulin (see figure 1). C-peptide is an attractive surrogate marker of insulin secretion because it can be used in patients administered exogenous insulin therapy and it is more reflective of insulin secretion than insulin itself, due to the variable clearance of insulin by the liver before it reaches the peripheral circulation ${ }^{1}$. C-peptide metabolism largely occurs in the kidney through glomerular filtration and uptake by tubular cells from peritubular capillaries, with $5-10 \%$ normally excreted in the urine. This is in contrast to insulin, $50 \%$ of which is metabolised and extracted in the liver. The total quantity of C-peptide excreted in the urine per day represents $5 \%$ of pancreatic secretion, compared to only $0.1 \%$ of secreted insulin ${ }^{2}$. Consequently, despite equimolar secretion, C-peptide has a longer halflife of approximately 30 minutes compared with only 6 minutes for insulin and occurs in the blood in concentrations up to five times higher than insulin ${ }^{3,4}$.

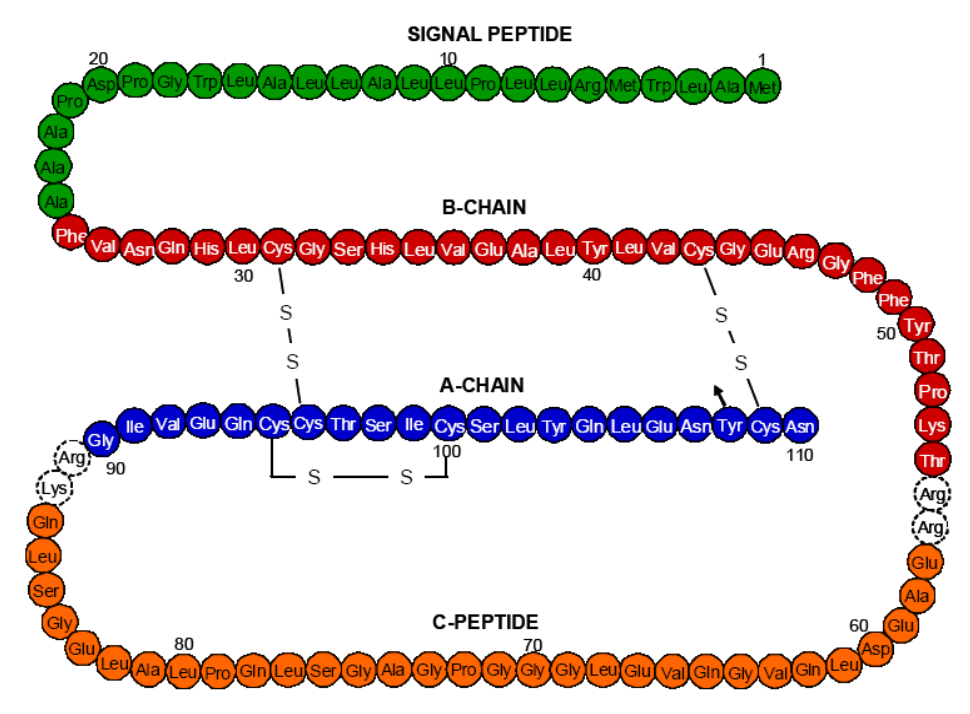

Figure 1: Diagram of pro-insulin demonstrating the A chain and B chain of insulin and the connecting peptide (Cpeptide), figure adapted from Stoyet al $2007^{5}$. During the biosynthesis of insulin, the $\mathrm{C}$ peptide promotes proper protein folding and disulfide bonds between the A and B chains. 


\section{C-peptide and differentiating subtypes of diabetes}

The assessment of endogenous C-peptide production in diabetes can be useful in classifying the sub-type of diabetes. In a patient with young onset diabetes persistent Cpeptide production may reflect the honeymoon period of a patient with Type 1 diabetes, but also enduring C-peptide can be a feature of other types of diabetes including Type 2 diabetes where levels are typically high.

There is extensive evidence that C-peptide can be used to differentiate between the classification of Type 1 diabetes and Type 2 diabetes ${ }^{6-10}$. C-peptide is a good candidate biomarker to differentiate patients with Maturity Onset Diabetes of the Young (MODY) from Type 1 diabetes. Type 1 diabetes is characterised by autoimmune destruction of beta-cells and ultimately results in absolute insulin deficiency, usually within 5 years of diagnosis ${ }^{11}$. In patients with a genetic diagnosis of MODY, beta cell function is typically maintained with time despite a reduction in insulin secretion and progressive hyperglycaemia ${ }^{12}$.The ISPAD Clinical Practise Consensus Guidelines 'Compendium on the diagnosis and management of monogenic diabetes in children and adolescents' published in $2009^{13}$ and best practice guidelines for the molecular genetic diagnosis of maturity-onset diabetes of the young, published in $2008{ }^{14}$ both acknowledge that persistent C-peptide production can be used to identify patients likely to harbour a mutation in a MODY gene. Both guidelines suggest after the initial honeymoon period in patients with suspected Type 1 diabetes (typically $>5$ years) a blood C-peptide level of $>200 \mathrm{pmol} / \mathrm{L}$ suggests a possible diagnosis of MODY. These guidelines are supported by recent reports which have shown that a urine C-peptide can be used to discriminate Type 1 diabetes from MODY with a high sensitivity and specificity ${ }^{15,16}$

\section{Measurement of C-peptide}

Blood C-peptide

Standard measures of C-peptide involve blood samples collected either fasted or, most often, after a fixed stimulus (such as oral glucose, mixed meal or IV glucagon) ${ }^{1,17,18}$. Despite 
the established clinical utility of blood C-peptide measurement, its widespread use is limited. In many instances this is due to practical restrictions associated with sample collection. Both insulin and C-peptide concentrations are widely considered to be unstable and require specific pre-analytical handling procedures with many laboratory providers stipulating the need for blood samples to be rapidly centrifuged after collection on ice and the serum or plasma immediately frozen following separation from cells ${ }^{1,19}$. However, these strict handling protocols may not be necessary as there is evidence that C-peptide is stable for up to 24 hours on whole blood if collected into EDTA preservative ${ }^{20}$.

\section{Urine C-peptide}

There is a body of evidence that suggests 24 hour urine C-peptide (UCP) levels provide an accurate means of assessing beta cell-secretory capacity and correlate with both fasting and stimulated serum insulin and C-peptide ${ }^{2,8,21,22}$.

However, the cumbersome nature and difficulties in obtaining an accurate and complete 24 hour urine collection has limited the utility of this test ${ }^{23-25}$. Urine samples collected over a period of four hours and single post stimulated UCP have been shown to be significantly correlated with serum insulin and serum C-peptide in non-diabetic subjects ${ }^{26}$, and in insulin treated diabetic patients ${ }^{7}$. Correcting for creatinine adjusts urine C-peptide concentration for variation in urine concentration and enables the use of 'spot' urine samples in place of 24-h urine collection. Urinary C-peptide when collected in boric acid is stable for up to three days at room temperature making it possible to be collected remotely from the processing laboratory and even posted into the laboratory by patients ${ }^{27}$. Urine C-peptide creatinine ratio correlates strongly with blood C-peptide and has been validated in non-diabetics, type 1 diabetes, type 2 diabetes, adults and children ${ }^{15,16,28-35}$.

\section{C-peptide assays}

Early assays for C-peptide were radioimmunoassays and suffered from poor analytical sensitivity and specificity and are time-consuming to perform (and therefore expensive) 1,36,37. The introduction of non-isotopic assays (chemiluminescence, fluorescence, etc.) that 
utilise monoclonal antibodies has improved analytical sensitivity, specificity, reproducibility and reduced assay costs (to approximately £10). These technologies are also amenable to automation, allowing these assays to be incorporated into large high throughput clinical analysers.

\section{MATERIALS}

- Urine collected into boric acid container. For interpretation of beta-cell reserve, the sample should be a stimulated sample, collected 2 hours after the biggest meal of the day (see Methods section on patient preparation)

- Roche Modular Analytics E170 immunoassay analyser (Roche Diagnostics, Mannheim, Germany).

- C-peptide calibration material: Roche C-peptide Calibration Set (Roche Diagnostics, Mannheim, Germany)

- C-peptide quality control material: Elecsys Precicontrol Multianalyte (Roche Diagnostics, Mannheim, Germany)

- Roche C-peptide chemiluminescence assay kit (Roche Diagnostics, Mannheim, Germany)

- Diluent used for C-peptide assay (Equine serum albumin): Roche Diluent MultiAssay (Roche Diagnostics, Mannheim, Germany)

- Roche Creatinine modified Jaffe assay kit (Roche Diagnostics, Mannheim, Germany)

- Creatinine calibration material: Roche Calibrator for automated systems (Roche Diagnostics, Mannheim, Germany)

- Creatinine QC material: Randox assayed urine control level 2 \& 3 (Randox UK, Co. Antrim, United Kingdom) 


\section{METHODS}

Patient preparation: To assess the maximum endogenous C-peptide response, a stimulated urine sample should be collected. Patients should be briefed with the following information before sample collection:

1. Pass urine just before the biggest meal of the day and discard.

2. Eat the meal as usual with a glass or more of water.

3. Do not eat anything else for the next 2 hours unless you have a hypoglycaemic episode, in which case you should do this test on another day. You can drink water freely throughout the duration of the collection.

4. 2 hours after this meal, collect urine and send for analysis.

\section{Sample storage and stability}

Urine C-peptide concentration is unchanged at room temperature for $24 \mathrm{~h}$ and at $4{ }^{\circ} \mathrm{C}$ for 72 $h$ even in the absence of preservative.

Urine C-peptide collected in boric acid is stable at room temperature for 72 hours. Urine Cpeptide remained stable after 7 freeze-thaw cycles but decreased with freezer storage time and dropped to $82 \%-84 \%$ of baseline by 90 days at $-20^{\circ} \mathrm{C}^{27}$.

\section{Roche assay used to measure C-peptide in urine}

C-peptide analysis is performed on the high throughput Roche Modular Analytics E170 immunoassay analyser (Roche Diagnostics, Mannheim, Germany). The assay is a heterogeneous sandwich immunoassay. Urine is diluted 10-fold with Multi Assay Diluent . One biotinylated anti-C-peptide specific monoclonal mouse antibody and a second monoclonal antibody to C-peptide labelled with a ruthenium complex, react with C-peptide in $20 \mu \mathrm{L}$ of diluted urine sample to form an antigen-antibody-antigen sandwich complex. Separation is achieved via interaction of biotin and streptavidin attachment to paramagnetic microparticles (solid phase). The detection system employs electrochemiluminescence with ruthenium trisbipyridyl as the label.

Page $\mid 7$ 
Electrochemiluminescence occurs at $620 \mathrm{~nm}$ and readings are taken by the photomultiplier tube. The intensity of light signal is proportional to the concentration of C-peptide in the serum. All urine samples were pre-diluted 1:10 with equine serum albumin (diluent multianalyte, Roche Diagnostics, Mannheim, Germany). (See Note 2). The analysis time is 18 minutes per specimen. The E170 is able to analyse 170 samples per hour. The assay was calibrated using Roche C-peptide CalSet calibration material (Roche Diagnostics, Mannheim, Germany), traceable to WHO International Reference Reagent (IRR) for C-peptide of human insulin for immunoassay (IRR code $84 / 510)^{38}$. Quality Control was performed on each day of analysis using low level $(0.67 \mathrm{nmol} / \mathrm{L})$ and high level (3.33 nmol/L) PreciControlMultiAnalyte.

\section{Measuring range}

The measuring range of the urine C-peptide assay is from $0.03-133 \mathrm{nmol} / \mathrm{L}$. There is approximately $30 \%$ cross-reactivity with pro-insulin (see Note 3 )

\section{Roche assay used to measure creatinine in urine}

Creatinine is analysed on the Roche P modular analyser (Roche Diagnostics, Mannheim, Germany). The test principle is a kinetic colorimetric assay based on the Jaffé reaction as described by Popper et al., 1937 and modified by Bartels et al. in $1972^{39}$. In alkaline solution, creatinine forms a yellow-orange complex with picrate. The colour intensity is directly proportional to the concentration of creatinine in the urine sample and is measured photometrically at $500 \mathrm{~nm}$.

The assay was calibrated on each day of analysis using a two point calibration with Roche Calibrator for Automated Systems calibration material, traceable to Isotope Dilution-Mass Spectrometry (ID-MS) reference method. Quality Control was performed on each day of analysis using Randox assayed urine control level 2 \& 3 
Measuring range, units

The measuring range for creatinine in urine is $0.36-57.5 \mathrm{mmol} / \mathrm{L}$.Samples that have a creatinine concentration greater than this may be diluted 1:2 via the automatic re-run function, using saline as a diluent.

\section{Interpretation of results}

UCPCR is restricted to use in patients on insulin treatment to assess endogenous insulin secretion. Its role in patients not on insulin treatment is limited.

If the of UCPCR result is not in keeping with other clinical finding then we would recommend repeating the test especially if it is unexpectedly low. Patients tipping out boric acid preservative from urine collection tube, in a sample taking more than 3 days to reach the laboratory can result in artificially low results ${ }^{27}$. We are not aware of any reason or experience a falsely high value.

Most of the studies have been performed in patients with normal renal function (eGFR>60 $\mathrm{mL} / \mathrm{min} / 1.73 \mathrm{~m}^{2}$ ) but it has been validated in patients with Type 2 diabetes with moderate renal impairment (eGFR $30-60 \mathrm{~mL} / \mathrm{min} / 1.73 \mathrm{~m}^{2}{ }^{30}$. The test is unlikely to be appropriate in patients with severe renal impairment.

What values are expected in the different subtypes?

The UCPCR result is best measured on a post prandial sample taken approximately two hours after a meal stimulus. The interpretation depends on the specific clinical scenario i.e. type of diabetes and treatment. Median and $5-95^{\text {th }}$ percentile UCPCR values for non-diabetic controls, long standing Type 1 diabetes(> 5 years), Type 1 diabetes in the first five years after diagnosis, Type 2 diabetes (OHA and insulin treated) and patients with a genetic diagnosis of Maturity Onset Diabetes of the Young (MODY) are presented in table 1. 


\begin{tabular}{|c|c|c|c|c|c|c|c|c|c|c|}
\hline \multirow[b]{2}{*}{ Patient Group } & \multicolumn{5}{|c|}{$\begin{array}{c}\text { Males } \\
\text { UCPCR }(\mathrm{nmol} / \mathrm{mmol})\end{array}$} & \multicolumn{5}{|c|}{$\begin{array}{c}\text { Females } \\
\text { UCPCR }(\mathrm{nmol} / \mathrm{mmol})\end{array}$} \\
\hline & 5 th & 25th & 50th & 75th & 95th & 5 th & 25th & 50th & 75th & 95th \\
\hline Controls & 0.58 & 1.64 & 2.84 & 7.04 & 10.39 & 1.82 & 3 & 4.04 & 6.99 & 10.37 \\
\hline $\begin{array}{c}\text { Type } 1 \\
\text { Diabetes } \\
>5 \text { years } \\
\text { duration } \\
<5 \text { years } \\
\text { duration }\end{array}$ & $\begin{array}{c}<0.02 \\
0.02\end{array}$ & $\begin{array}{r}<0.02 \\
0.55\end{array}$ & $\begin{array}{l}0.02 \\
1.24\end{array}$ & $\begin{array}{l}0.02 \\
1.79\end{array}$ & 0.02 & $\begin{array}{l}0.00 \\
0.02\end{array}$ & $\begin{array}{l}0.00 \\
0.55\end{array}$ & 0.02 & 0.04 & $\begin{array}{l}0.04 \\
5.78\end{array}$ \\
\hline $\begin{array}{c}\text { Type } 2 \\
\text { Diabetes } \\
\text { On OHA } \\
\text { On insulin }\end{array}$ & $\begin{array}{l}0.35 \\
0.08\end{array}$ & $\begin{array}{l}1.6 \\
0.5\end{array}$ & $\begin{array}{c}2.87 \\
1.3\end{array}$ & $\begin{array}{l}4.08 \\
2.36\end{array}$ & $\begin{array}{l}7.80 \\
5.65\end{array}$ & $\begin{array}{l}1.28 \\
0.15\end{array}$ & $\begin{array}{c}2.34 \\
0.6\end{array}$ & $\begin{array}{c}3.85 \\
1.4\end{array}$ & $\begin{array}{c}5.68 \\
2.8\end{array}$ & $\begin{array}{l}9.43 \\
6.12\end{array}$ \\
\hline $\begin{array}{c}\text { HNF 1/4A } \\
\text { On OHA } \\
\text { On Insulin }\end{array}$ & $\begin{array}{l}0.54 \\
0.10\end{array}$ & $\begin{array}{l}1.36 \\
0.54\end{array}$ & $\begin{array}{l}1.84 \\
1.12\end{array}$ & $\begin{array}{l}2.80 \\
1.72\end{array}$ & $\begin{array}{l}6.10 \\
3.47\end{array}$ & $\begin{array}{l}0.54 \\
0.10\end{array}$ & $\begin{array}{l}1.23 \\
0.54\end{array}$ & $\begin{array}{l}2.93 \\
1.12\end{array}$ & $\begin{array}{l}4.04 \\
1.72\end{array}$ & $\begin{array}{c}10.02 \\
3.47\end{array}$ \\
\hline
\end{tabular}

Table 1: UCPCR ranges in diabetes subtypes and controls (unpublished data). 


\section{NOTES}

\section{1- Agreement of urine C-peptide measurements in different commercially}

available assays - There is poor comparability between commercial and in-house Cpeptide assays making transferability of C-peptides values/cut-offs from research to clinical practice problematic ${ }^{40-42}$. International working groups (in the USA and Europe) are currently addressing the widely disparate values between analytical methods for both C-peptide and insulin ${ }^{40,42,43}$. The groups are combining efforts to improve standardisation with the aim of establishing a complete reference measurement system and certified primary reference materials based on pure biosynthetic insulin and C-peptide ${ }^{43}$.

2- Using other diluents in the Roche C-peptide assay- C-peptide is approximately 20 fold more concentrated in urine samples and therefore require dilution before analysis. We have found that the diluent must be proteinaceous (e.g. equine serum albumin) in order to achieve both a concentration and matrix that will generate a comparable and reproducible result. This has been shown for three different platforms measuring C-peptide (Roche, Immunlite and Centaur).(*unpublished data derived at the Blood Sciences Dept, RD\&E)

3- Cross reactivity of the Roche assay with proinsulin- Proinsulin does cross react with the Roche assay ( $30 \%$ cross reactivity) despite the fact that the assay utilises two site monoclonal antibodies. However, proinsulin and split products exist in much lower concentrations than C-peptide in serum $(<2 \%$ in non-diabetics) and are therefore of little clinical significance except for in rare conditions such as insulinoma 44. In addition, the total quantity of C-peptide excreted in the urine per day represents $5-10 \%$ of pancreatic secretion, compared to only $0.05 \%$ of secreted proinsulin (2-3 times lower than insulin of which only $0.1 \%$ is excreted into the urine ${ }^{45}$ ). With only 
$30 \%$ cross reactivity in the Roche assay the contribution of proinsulin to urine Cpeptide measurement would be negligible.

4- Making a diagnosis in insulin treated patients- The principal role of urinary Cpeptide is to identify insulin insufficiency, a feature of long term Type 1 diabetes, in insulin treated patients. We have found that $>95 \%$ Type 1 diabetes ( $>5$ year duration) have a UCPCR value $<0.2 \mathrm{nmol} / \mathrm{mmol}$.

\section{○ Type 1 v MODY}

A cut-off UCPCR of $0.2 \mathrm{nmol} / \mathrm{mmol}$ differentiates HNF1A/4A MODY from Type 1 diabetes with a sensitivity of $97 \%$ and specificity of $96 \%(\mathrm{ROC} 0.98)^{15}$.

○ Type 1 v Type 2

A cut-off of $0.2 \mathrm{nmol} / \mathrm{mmol}$ differentiates Type 2 diabetes from Type 1 diabetes with $94 \%$ sensitivity and $94 \%$ specificity (ROC AUC 0.94 ).

\section{5- Monitoring the honeymoon period in Type 1 diabetes}

In patients with Type 1 diabetes it is possible to measure the extent to which they are progressing through the honeymoon phase. UCPCR is highly correlated with the serum $\mathrm{C}$ peptide in a formal mixed tolerance test ${ }^{32}$

\section{6- Assessing in insulin treated Type 2 diabetes the extent of endogenous insulin} secretion

Endogenous insulin secretion can be measured in Type 2 diabetes. UCPCR is highly correlated with the serum C-peptide in a formal mixed tolerance test ${ }^{29}$. Patients with a high endogenous secretion $>75^{\text {th }}$ centile (table 1 ) are likely be those that benefit most from metformin and other oral agents. Patients with low endogenous insulin secretion $<25^{\text {th }}$ centile and particularly if UCPCR $<0.02$ $\mathrm{nmol} / \mathrm{mmol}$ will most likely require insulin therapy.

\section{ACKNOWLEDGEMENTS}

Page | 12 
Tim McDonald is a National Institute of Health Research CSO funded scientist. The views

expressed are those of the author(s) and not necessarily those of the NHS, the NIHR or the

Department of Health.

\section{REFERENCES}

1. Clark PM. Assays for insulin, proinsulin(s) and C-peptide. Ann Clin Biochem 1999;36 ( Pt 5):541-64.

2. Horwitz DL, Rubenstein AH, Katz AI. Quantitation of human pancreatic beta-cell function by immunoassay of C-peptide in urine. Diabetes 1977;26:30-5.

3. Matthews DR, Rudenski AS, Burnett MA, Darling P, Turner RC. The half-life of endogenous insulin and C-peptide in man assessed by somatostatin suppression. Clinical endocrinology 1985;23:71-9.

4. Duckworth WC, Bennett RG, Hamel FG. Insulin degradation: progress and potential. Endocr Rev 1998;19:608-24.

5. Stoy J, Edghill EL, Flanagan SE, et al. Insulin gene mutations as a cause of permanent neonatal diabetes. Proc Natl Acad Sci U S A 2007;104:15040-4.

6. Hattersley A, Bruining J, Shield J, Njolstad P, Donaghue K. ISPAD Clinical Practice Consensus Guidelines 2006-2007. The diagnosis and management of monogenic diabetes in children. Pediatr Diabetes 2006;7:352-60.

7. Koskinen P, Viikari J, Irjala K, Kaihola HL, Seppala P. Plasma and urinary C-peptide in the classification of adult diabetics. Scand J Clin Lab Invest 1986;46:655-63.

8. Gjessing HJ, Matzen LE, Faber OK, Froland A. Fasting plasma C-peptide, glucagon stimulated plasma C-peptide, and urinary $\mathrm{C}$-peptide in relation to clinical type of diabetes. Diabetologia 1989;32:305-11.

9. Berger B, Stenstrom G, Sundkvist G. Random C-peptide in the classification of diabetes. Scand J Clin Lab Invest 2000;60:687-93.

10. Service FJ, Rizza RA, Zimmerman BR, Dyck PJ, O'Brien PC, Melton LJ, 3rd. The classification of diabetes by clinical and C-peptide criteria. A prospective population-based study. Diabetes Care 1997;20:198-201.

11. Palmer JP, Fleming GA, Greenbaum CJ, et al. C-peptide is the appropriate outcome measure for type 1 diabetes clinical trials to preserve beta-cell function: report of an ADA workshop, 21-22 October 2001. Diabetes 2004;53:250-64.

12. Byrne MM, Sturis J, Fajans SS, et al. Altered insulin secretory responses to glucose in subjects with a mutation in the MODY1 gene on chromosome 20. Diabetes 1995;44:699-704. 13. Hattersley A, Bruining J, Shield J, Njolstad P, Donaghue KC. The diagnosis and management of monogenic diabetes in children and adolescents. Pediatr Diabetes 2009;10 Suppl 12:33-42.

14. Ellard S, Bellanne-Chantelot C, Hattersley AT. Best practice guidelines for the molecular genetic diagnosis of maturity-onset diabetes of the young. Diabetologia 2008;51:546-53.

15. Besser RE, Shepherd MH, McDonald TJ, et al. Urinary C-Peptide Creatinine Ratio Is a Practical Outpatient Tool for Identifying Hepatocyte Nuclear Factor 1-\{alpha\}/Hepatocyte Nuclear Factor 4-\{alpha\} Maturity-Onset Diabetes of the Young From Long-Duration Type 1 Diabetes. Diabetes Care 2011;34:286-91. 
16. Besser RE, Shields BM, Hammersley SE, et al. Home urine C-peptide creatinine ratio (UCPCR) testing can identify type 2 and MODY in pediatric diabetes. Pediatr Diabetes 2013;14:181-8.

17. Bolner A, Lomeo L, Lomeo AM. "Method-specific" stability of serum C-peptide in a multicenter clinical study. Clin Lab 2005;51:153-5.

18. Greenbaum CJ, Mandrup-Poulsen T, McGee PF, et al. Mixed-meal tolerance test versus glucagon stimulation test for the assessment of beta-cell function in therapeutic trials in type 1 diabetes. Diabetes Care 2008;31:1966-71.

19. Assayfinder. (Accessed 28/07/11, 2011, at www.assayfinder.com.)

20. McDonald TJ, Perry MH, Peake RW, et al. EDTA improves stability of whole blood C-peptide and insulin to over 24 hours at room temperature. PLoS One 2012;7:e42084.

21. Gjessing HJ, Matzen LE, Froland A, Faber OK. Correlations between fasting plasma C-peptide, glucagon-stimulated plasma C-peptide, and urinary C-peptide in insulin-treated diabetics. Diabetes Care 1987;10:487-90.

22. Huttunen NP, Knip M, Kaar ML, Puukka R, Akerblom HK. Clinical significance of urinary C-peptide excretion in children with insulin-dependent diabetes mellitus. Acta paediatrica Scandinavica 1989;78:271-7.

23. Meistas MT, Zadik Z, Margolis S, Kowarski AA. Correlation of urinary excretion of C-peptide with the integrated concentration and secretion rate of insulin. Diabetes 1981;30:639-43.

24. Aoki Y. Variation of endogenous insulin secretion in association with treatment status: assessment by serum C-peptide and modified urinary C-peptide. Diabetes Res Clin Pract 1991; $14: 165-73$.

25. Cote AM, Firoz T, Mattman A, Lam EM, von Dadelszen P, Magee LA. The 24-hour urine collection: gold standard or historical practice? American journal of obstetrics and gynecology 2008;199:625 e1-6.

26. Hoogwerf BJ, Barbosa JJ, Bantle JP, Laine D, Goetz FC. Urinary C-peptide as a measure of beta-cell function after a mixed meal in healthy subjects: comparison of four-hour urine C-peptide with serum insulin and plasma C-peptide. Diabetes Care 1983;6:488-92. 27. McDonald TJ, Knight BA, Shields BM, Bowman P, Salzmann MB, Hattersley AT. Stability and reproducibility of a single-sample urinary C-peptide/creatinine ratio and its correlation with 24-h urinary C-peptide. Clin Chem 2009;55:2035-9.

28. Oram RA, Rawlingson A, Shields BM, et al. Urine C-peptide creatinine ratio can be used to assess insulin resistance and insulin production in people without diabetes: an observational study. BMJ Open 2013;3:e003193.

29. Jones AG, Besser RE, McDonald TJ, et al. Urine C-peptide creatinine ratio is an alternative to stimulated serum C-peptide measurement in late-onset, insulin-treated diabetes. Diabet Med 2011;28:1034-8.

30. Bowman P, McDonald TJ, Shields BM, Knight BA, Hattersley AT. Validation of a single-sample urinary $\mathrm{C}$-peptide creatinine ratio as a reproducible alternative to serum $\mathrm{C}$ peptide in patients with Type 2 diabetes. Diabet Med 2012;29:90-3.

31. Besser RE. Determination of C-peptide in children: when is it useful? Pediatr Endocrinol Rev 2013;10:494-502.

32. Besser RE, Ludvigsson J, Jones AG, et al. Urine C-peptide creatinine ratio is a noninvasive alternative to the mixed-meal tolerance test in children and adults with type 1 diabetes. Diabetes Care 2011;34:607-9.

33. Besser RE, Shields BM, Casas R, Hattersley AT, Ludvigsson J. Lessons from the mixed-meal tolerance test: use of 90-minute and fasting C-peptide in pediatric diabetes.

Diabetes Care 2013;36:195-201. 
34. Hope SV, Jones AG, Goodchild E, et al. Urinary C-peptide creatinine ratio detects absolute insulin deficiency in Type 2 diabetes. Diabet Med 2013;30:1342-8.

35. Thomas NJ, Shields BM, Besser RE, et al. The impact of gender on urine C-peptide creatinine ratio interpretation. Ann Clin Biochem 2012;49:363-8.

36. Ashby JP, Frier BM. Circulating C peptide: measurement and clinical application. Ann Clin Biochem 1981;18:125-30.

37. Koskinen P. Nontransferability of C-peptide measurements with various commercial radioimmunoassay reagents. Clin Chem 1988;34:1575-8.

38. Bristow AF, Das RE. WHO international reference reagents for human proinsulin and human insulin C-peptide. J Biol Stand 1988;16:179-86.

39. Bartels H, Bohmer M, Heierli C. [Serum creatinine determination without protein precipitation]. Clin Chim Acta 1972;37:193-7.

40. Wiedmeyer HM, Polonsky KS, Myers GL, et al. International comparison of Cpeptide measurements. Clin Chem 2007;53:784-7.

41. Little RR, Rohlfing CL, Tennill AL, et al. Standardization of C-peptide measurements. Clin Chem 2008;54:1023-6.

42. Marcovina S, Bowsher RR, Miller WG, et al. Standardization of insulin immunoassays: report of the American Diabetes Association Workgroup. Clin Chem 2007;53:711-6.

43. Miller WG, Thienpont LM, Van Uytfanghe K, et al. Toward standardization of insulin immunoassays. Clin Chem 2009;55:1011-8.

44. Vauhkonen IK, Niskanen LK, Mykkanen L, Haffner SM, Uusitupa MI, Laakso M. Hyperproinsulinemia is not a characteristic feature in the offspring of patients with different phenotypes of type II diabetes. Eur J Endocrinol 2000;143:251-60.

45. Constan L, Mako M, Juhn D, Rubenstein AH. The excretion of proinsulin and insulin in urine. Diabetologia 1975;11:119-23. 